\title{
Analysis of Risk Factors for the Incidence of Stunting in Toddlers
}

\author{
Andi Sastria Ahmad1, Abdul Azis², Fadli ${ }^{*}$ \\ 1) Nursing Study Program, Institute of Health Science Muhammadiyah Sidrap, Sulawesi Selatan, Indonesia \\ 2) Dental Health Study Program, Institute of Health Science Muhammadiyah Sidrap, Sulawesi Selatan, Indonesia \\ 3) Nurse Proffesional Study Program, Institute of Health Science Muhammadiyah Sidrap, Sulawesi Selatan, Indonesia \\ fadlietri@gmail.com \\ DOI: http://doi.org/10.29080/jhsp.v5i1.415
}

Received : Agustus 2020, Accepted : Januari 2021, Published : April 2021

\section{Keywords}

Posyandu; Role of Health Workers; Child Care Stunting

\begin{abstract}
Stunting may have occurred since prenatal phases until the baby was 2 years old because of malnutrition. Children having stunting have a problem in growth and cognitive impairments. This study aims to analyze the risk factors of stunting among children under five in Empagae, Sidrap Regency. This correlational research study the correlation between posyandu visits, health workers' roles, and parenting on stunting. Technique sampling used was consecutive sampling with 52 respondents. The results showed that there was a moderate correlation between the health workers roles and stunting ( $p$-value $=0.018 ; r=0.33$ ), strong correlation between parenting styles and stunting ( $p$. -value $=0.000 ; r=0.82$ ), and moderate correlation between posyandu visits stunting ( $p$-value $=0.002 ; r=0.43$ ). This research implies that mothers must fulfill nutrition to prevent stunting and be more active in posyandu activities to have nutrition monitoring. It is hoped that health workers have to control and monitor the nutritional status of toddlers, pregnant women, and mothers who have babies to prevent stunting.
\end{abstract}

\section{Introduction}

Since problems on nutrition have not been resolved globally, then it causes stunting among children under five. Stunting is a short or very short posture that causes a deficit of -2 SD below the median length or height physical condition which commonly occurs in children under 5 years old (1). The main causes of stunting are insufficient nutrition for a long period and not appropriate food intake with the nutritional needs of children (2). Stunting was started from nutritional deficiencies during pregnancy, breastfeeding, and up to 23 months which is called the first 1,000 days of life (3). Therefore, stunting is not only a nutrition problem for children under five nationally but also globally.

The prevalence of stunting globally is 149 million children under 5 years (4). In 2016, 36\% of people in Asia which was mostly found in South Asia have nearly half of all their children under five (61 million) are stunting (5). There are 34.5\% stunting in Africa, 52.4\% in Ethiopia, and 40\% in Congo (4)(6). Indonesia had $29.6 \%$ in 2017, then it increased in 2018 by $30.8 \%$. Some provinces have more than national data in which Aceh has 37.9\%, West Sulawesi has 36.7\%, and South Sulawesi has 33.8\% (7).

The stunting not only make impairment in cognitive, motoric, and verbal development but also the risk of obesity (8). Besides, stunting also affects metabolic processes and decreases productivity in children (5). Research by Kang et al (2018), found that one-fifth of children in preschool were stunting because of malnourishment (9). Other research explains that stunting is a growth disorder in children under five because of malnutrition and it can causes low intelligence in the long-term process if it is not treated properly (10). Therefore, stunting must be prevented since the prenatal phases.

Stunting can be prevented by having good quality and quantity nutrition through family active roles (1). Pertiwi et al. (2019), argued that poor mother's parenting can make stunting in children, lead to poor nutritional status, and affect children's growth and development (11). Other studies explain a significant correlation between family characteristics and parenting styles on stunting. Besides, the family must be 
active in visiting posyandu to get knowledge about nutrition for children's growth and development (5). To gain knowledge, a family must be more active in visiting integrated service posts.

Not only health workers but also the community have a role to promote nutrition for children to solve malnutrition and stunting (12). Since parents are not active visiting posyandu, then they don't get information about integrated nutrition programs for 3 months which are evaluated by health workers (13).

A mother who actively visits posyandu not only has nutritional status monitoring but also gets the latest information on health for a healthy lifestyle (14). Theresia (2020) explained that the more routine they visit posyandu, the better nutritional status they have for their children. $69 \%$ of children who routinely monitored only $43 \%$ have good nutritional status (15). In short, this study aims to study risk factors affecting stunting among children under five in Empagae Puskesmas, Sidrap Regency.

\section{Methods}

This cross-sectional correlation research was carried out from May to June 2020 in Empagee Puskesmas working area. Stunting was a dependent variable while the role of officers, family parenting, and posyandu visits are independent variables.

The research population was 64 mothers who had children under five in Empagae puskesmas working area. 52 sample was chosen using consecutive technique sampling. Criteria for respondents are mothers who have toddlers, live in puskesmas working area, can communicate well, and have a will to be respondents. All participants agree with the research protocol and sign the informed consent. This research has been approved by the STIKES Muhamadiyah Sidrap Ethics Committee with Number 062 / KEP / II.3.AU / F / 2020 and takes into account the principles in the research process.

This research aims to study the correlation between risk factors and stunting among children under five years. Data was collected using a questionnaire which consists of demographic data, the role of officers (16 questions), parenting styles (18 questions), and posyandu visit (8 questions). Besides, the observation sheet through the KMS book and questionnaires about the nutritional status also attached. The questionnaire was adopted from Destiadi et al. (2015); Astuti et al. (2020); Bella et al (2020). Data were analyzed using somers'd correlation test with statistical software SPSS version 20.0 (IBM Corp).

\section{Results}

Table 1. Frequency Distribution Based on Characteristics of Respondents in the Work Area of the Public Health Center of Empagae, Sidrap Regency

\begin{tabular}{cccc}
\hline No & Respondent Characteristics & $\mathbf{n}$ & $\mathbf{\%}$ \\
\hline 1. & Age of mother (years) & & \\
& $17-25$ & 27 & 51,9 \\
& $26-35$ & 17 & 32,7 \\
& $>35$ & 8 & 15,4 \\
2. & Age of toddlers (months) & 27 & 51,9 \\
& $12-24$ & 27 & 48,1 \\
3. & $25-60$ & 25 & 36,4 \\
& Employment status of mother & & 65,4 \\
& Working & 18 & 73,1 \\
& Not working & 34 & 26,9 \\
\hline & Parents' income & & $\mathbf{1 0 0}$ \\
\hline
\end{tabular}

Table 1 showed that most mothers are at the age of $17-25$ years old Then $51.9 \%$ of them are having 12-24 months toddlers and 48,1\% having 25-60 months toddlers. Around 65.4\% family have no job and $73.1 \%$ family having husbands with good incomes. 
Table 2. Frequency distribution based on the role of officers, parenting style, posyandu visits, and stunting

\begin{tabular}{|c|c|c|}
\hline Variable & Number & $\%$ \\
\hline \multicolumn{3}{|l|}{ Officer role } \\
\hline Good & 39 & 75,0 \\
\hline Less & 13 & 25,0 \\
\hline \multicolumn{3}{|l|}{ Parenting style } \\
\hline Good & 31 & 59,6 \\
\hline Less & 21 & 40,4 \\
\hline \multicolumn{3}{|c|}{ Visits to integrated service posts } \\
\hline Active & 37 & 71,2 \\
\hline Not active & 15 & 28,8 \\
\hline \multicolumn{3}{|l|}{ Stunting incidence } \\
\hline Normal & 34 & 65,4 \\
\hline Stunting & 18 & 34,6 \\
\hline Total & 52 & 100 \\
\hline
\end{tabular}

Table 2 shows that the role of health workers preventing stunting is $75 \%$, good parenting is $59.6 \%$, and poor nutrition is $40.4 \%$ toddlers because of bad parenting in taking care of their nutrition. Considering the frequency of visits, mothers having visited once a month at $71.2 \%$. The number of children under five is mostly normal at $65.4 \%$, but $34.6 \%$ are still having stunting.

Table 3. Correlation between roles of officers, parenting styles, posyandu visits, and stunting in Empagae, Sidrap Regency

\begin{tabular}{|c|c|c|c|c|c|c|c|c|}
\hline \multirow{3}{*}{ Variable } & \multicolumn{4}{|c|}{ Stunting Incident } & \multirow{2}{*}{\multicolumn{2}{|c|}{ Total }} & \multirow{3}{*}{$\mathbf{R}$} & \multirow{3}{*}{$p$} \\
\hline & \multicolumn{2}{|c|}{ Normal } & \multicolumn{2}{|c|}{ Stunting } & & & & \\
\hline & $\mathbf{n}$ & $\%$ & $\mathbf{n}$ & $\%$ & $\mathbf{n}$ & $\%$ & & \\
\hline \multicolumn{9}{|l|}{ Officer Role } \\
\hline Good & 29 & 55.8 & 10 & 19.2 & 39 & 75.0 & \multirow{2}{*}{0.33} & \multirow{2}{*}{0.018} \\
\hline Less & 5 & 9.6 & 8 & 15.4 & 13 & 25.0 & & \\
\hline \multicolumn{9}{|l|}{ Parenting style } \\
\hline Good & 30 & 57.7 & 1 & 1.9 & 31 & 59.6 & \multirow[t]{2}{*}{0.82} & \multirow[t]{2}{*}{0.000} \\
\hline Less & 4 & 7.7 & 17 & 32.7 & 21 & 40.4 & & \\
\hline \multicolumn{9}{|c|}{$\begin{array}{l}\text { Visit to integrated } \\
\text { service post }\end{array}$} \\
\hline Active & 29 & 55.8 & 8 & 15.4 & 37 & 71.2 & \multirow[t]{2}{*}{0.43} & \multirow[t]{2}{*}{0.002} \\
\hline Less active & 5 & 9.6 & 10 & 19.2 & 15 & 28.8 & & \\
\hline
\end{tabular}

Table 3 showed that officers' role has a significant correlation with stunting among children under five ( $\mathrm{p}$-value $=0.018$. Having $\mathrm{r}$ value 0.33 explaining that $33.0 \%$ officers role affects stunting. Besides, parenting style has a strong effect on stunting, $82.0 \%$. with a significant correlation $(p$-value $=0.000)$. Then, posyandu visits also have a significant correlation with stunting ( $p$-value $=0.002)$ with $r=0.43$ meaning that $43.0 \%$ posyandu visits affect preventing the risk of stunting.

\section{Discussion}

The result showed a positive role of officers who are actively providing treatment and prevention of stunting. The lower numbers of stunting cases describing the effort of health workers. They provide information and share education-related to stunting risk factors through posyandu activity. A good education makes a positive impact both on mothers and toddlers since their knowledge improved and nutrition intake increased(15).

According to Health Ministry (2019), since stunting was caused by multidimensional factors then it needs multi-sectors to handle it. Health workers young officer monitoring the nutritional status of children before 2 years (16). They give knowledge about health, children's growth, and development (17). Astuti et al research (2018), also found a correlation between the ability of health workers to detect stunting, water, and environmental sanitation, parenting. places giving birth and genetic factors (18). Therefore, not only health workers roles but also parents are very important in overcoming the stunting in providing good and nutrition for children.

Besides, the results show that poor parenting was influenced by several factors. Since most respondents are working 6 days a week from morning to evening, they rarely interact with their children and only have 4 hours at night. Family income also affects nutrition and parenting styles. 
This study supported the previous finding in which there was a significant correlation between parenting and stunting. Children from mothers with poor parenting are 4.263 times higher at risk of stunting than mothers with good parenting (19). Good parenting can be influenced by knowledge in providing nutrition for children's growth and development. According to Gunardi et al. (2017) research, there were 14 children (8.7\%) having decreased growth, and 10 children (6.2\%) are stunting. It was affected by their parents' knowledge about linear growth in children less than 2 years (20). To prevent stunting on children can be in a form of eating habits, sanitation, and healthy habits (21). Quality and quantity nutrition should be fulfilled through active visit posyandu so that children's growth and development can be monitored (1).

Posyandu visits have a $43.0 \%$ effect on stunting on children. Visiting posyandu activity makes a mother having toddlers get monitoring on nutrition status and information about healthy habit for every day (14). Posyandu had monitoring children's growth and development every month with KMS monitoring card to detect early developmental problems in children (17). It helps to decrease stunting prevalence in a year. Theresia (2020) stated that mothers who routinely visit posyandu will have toddlers with better nutrition status. Posyandu not only gives nutrition food and vitamin, but bu also monitor nutrition status. The result showed that $69.0 \%$ actively visit posyandu while $43 \%$ do not (15).

\section{Conclusion}

This research conclude that there is a correlation between the role of health workers, parenting styles, and posyandu visits to stunting in children under five. Parenting variable had a dominant effect on stunting in which good parenting can fulfill nutrition. Parents are suggested to visit posyandu every month so that their toddler can get monitoring of their growth and development.

\section{Acknowledgements}

We would like to thank to the Ministry of Research and Technology especially the National Research and Innovation Division for funding lecturers' research grants. Our gratitude also goes to the Institute for Research and Community Service of STIKES Muhammadiyah Sidrap for facilitating this research process.

\section{References}

1. Yarmaliza, Syahputri VN. Kaldu Tempe Sebagai Intervensi Spesifik Dalam Pencegahan Stunting. J Kesehat. 2020;11(1):1-7.

2. Lestari EF, Dwihestie LK. ASI Eksklusif Berhubungan dengan Kejadian Stunting pada Balita. J Ilm Permas [Internet]. 2020;10(2):129-36. Available from: http://journal.stikeskendal.ac.id/index.php/PSKM/article/view/731

3. Bolte EE, Aagaard KM. Turning the "Phage" on Malnutrition and Stunting. Cell Host Microbe [Internet]. 2020;27(2):159-61. Available from: https://doi.org/10.1016/j.chom.2020.01.020

4. WHO. Levels and Trends in Child malnutrition [Internet]. UNICEF / WHO / World Bank Group Joint Child Malnutrition Estimates. 2019. p. 1-16. Available from: https://www.who.int/nutgrowthdb/jme2019-key-findings.pdf\%0Ahttp://www.unicef.org/media/files/JME_2015_edition_Sept_2015.pdf

5. Utami RA, Setiawan A, Fitriyani P. Identifying causal risk factors for stunting in children under five years of age in South Jakarta, Indonesia. Enferm Clin. 2019;29:606-11.

6. Budiastutik I, Rahfiludin MZ. Faktor Risiko Stunting pada anak di Negara Berkembang Risk Factors of Child Stunting in Developing Countries. Amerta Nutr. 2019;3(3):122-6.

7. Kementerian Kesehatan RI. Hasil Utama Riset Kesehata Dasar (RISKESDAS) [Internet]. Badan Penelitian dan Pengembangan Kesehatan. 2018. p. 1-200. Available from: https://kesmas.kemkes.go.id/assets/upload/dir_519d41d8cd98f00/files/Hasil-riskesdas2018_1274.pdf

8. Yadika ADN, Berawi KN, Nasution SH. Pengaruh Stunting terhadap Perkembangan Kognitif dan Prestasi Belajar. J Major [Internet]. 2019;8(2):273-82. Available from: https://juke.kedokteran.unila.ac.id/index.php/majority/article/view/2483

9. Kang Y, Aguayo VM, Campbell RK, Dzed L, Joshi V, Waid JL, et al. Nutritional status and risk factors for stunting in preschool children in Bhutan. Matern Child Nutr. 2018;14(February):1-16.

10. Rahayu RM, Pamungkasari EP, Wekadigunawan. The Biopsychosocial Determinants of Stunting and Wasting in Children Aged 12-48 Months. J Matern Child Heal. 2018;3(2):105-18.

11. Pertiwi MR, Lestari P, Ulfiana E. Relationship Between Parenting Style and Perceived Information Sources With Stunting Among Children. Int J Nurs Heal Serv. 2019;2(4):273-9.

12. Kementerian Kesehatan RI. Penyebab Stunting pada Anak [Internet]. 2018. Available from: http://www.depkes.go.id/article/view/18052800006/ini-penyebab-stunting-pada-anak.html

13. Wijayanti HN, Fauziah A. Efforts of The Integrated Health Post Cadres for Improving Nutritional Status 
of Stunted Children. In: International Conference on Public Health. Solo, Indonesia: ICPH; 2019. p. 354354.

14. Destiadi A, Susila T, Sumarmi S. Frekuensi Kunjungan Posyandu dan Riwayat Kenaikan Berat badan sebagai Faktor Risiko Kejadian Stunting pada Anak Usia 3-5 Tahun. Media Gizi Indones. 2015;10(1):71-5.

15. Theresia D. Hubungan Jumlah Kunjugan Ibu Ke Posyandu dengan Status Gizi Balita Di Wilayah Kerja Puskesmas Amplas. J Keperawatan Prior. 2020;3(2):31-41.

16. Dwijayanti F, Setiadi H. Pentingnya kesehatan masyarakat, edukasi dan pemberdayaan perempuan untuk mengurangi stunting di negara berkembang. J Semin Nas [Internet]. 2020;2(1):16-25. Available from: http://ejurnalstikesrespati-tsm.ac.id/index.php/semnas/article/view/246

17. Kemenkes RI. Kebijakan dan Strategi Penanggulangan Stunting Di Indonesia. Jakarta; 2019.

18. Astuti S, Megawati G, Samson. Gerakan Pencegahan Stunting Melalui Pemberdayaan Masyarakat Di Kecamatan Jatinangor Kabupaten Sumedang. J Apl Ipteks. 2018;7(3):185-8.

19. Silas L, Rantetampang AL, Tingginehe R, Mallongi A. The Factors Affecting Stunting Child under Five Years in Sub Province Mimika. Int J Sci Healthc Res. 2018;3(2):99-108.

20. Gunardi H, Soedjatmiko, Sekartini R, Medise BE, Darmawan AC, Armeilia R, et al. Association between parental socio-demographic factors and declined linear growth of young children in Jakarta. Med J Indones. 2017;26(4):286-92.

21. Bella FD, Fajar NA, Misnaniarti. Hubungan antara Pola Asuh Keluarga dengan Kejadian Balita Stunting pada Keluarga Miskin di Palembang. J Epidemiol Kesehat Komunitas [Internet]. 2020;5(1):15-22. Available from: https://ejournal2.undip.ac.id/index.php/jekk/article/download/5359/3746 